\title{
Minimally invasive hollow trephine technique is recommended for revision of broken uncemented and extensively porous-coated monolithic femoral stems: a review of three cases
}

\author{
Çimentosuz ve aşırı düzeyde poroz kaplamalı monolitik kırık femur başı revizyonu için minimal \\ invaziv delikli trepan tekniği önerilir: Üç olgu değerlendirmesi
}

\author{
Boris Steno, MD., PhD., ${ }^{1}$ Libor Necas, MD., PhD., ${ }^{2}$ Marian Melisik, MD., ${ }^{2}$ Jozef Almasi, MD., PhD. ${ }^{3}$ \\ 'Department of Orthopedics and Traumatology, University Hospital Bratislava, Slovakia \\ 2Department of Orthopedics and Traumatology, University Hospital Martin, Slovakia \\ ${ }^{3}$ Department of Orthopedics and Traumatology, General Hospital Dunajska Streda, Slovakia
}

\begin{abstract}
Revisions of fractured, uncemented and extensively porous-coated femoral stems are challenging. In this article, we report three cases of revision surgeries for broken, cementless, and extensively porous-coated femoral stems with Solution ${ }^{\mathrm{TM}}$ stems (DePuy, Warsaw, Indiana). In all cases, minimally invasive endofemoral revision was successfully performed without femoral osteotomy or cortical fenestration. Removal of distal broken femoral stem was performed with hollow trephine technique under fluoroscopy. For revision arthroplasty of the femoral component, Solution ${ }^{\mathrm{TM}}$ stems of larger diameter were used. Endofemoral approach reduces duration of surgery and the amount of blood and bone loss. Minimally invasive technique for broken and uncemented femoral stem is recommended.

Key words: Femoral stem; fracture; hollow trephine; porous-coated; revision.
\end{abstract}

Total hip arthroplasty has been used for almost over five decades as a well-established procedure. Increasing number of revision total hip replacements (THR) due to aseptic and septic complications. ${ }^{[1,2]}$ lead to the design of improved revision prostheses. Distally fixed, cementless, cylindrical femoral stems with an extensive porous coating are one of principal revision options in case of failed THR on the femoral side. These stems have been used in absence of adequate proximal femoral bone stock for over 30 years. ${ }^{[3]}$ Their design enables them to achieve a solid initial
Kırık, çimentosuz ve aşırı düzeyde poroz kaplamalı femur başlarının revizyonu güçtür. Bu yazıda, çimentosuz ve aşırı düzeyde poroz kaplamalı kırık femur başlarının Solution ${ }^{\mathrm{TM}}$ başlar (DePuy, Warsaw, Indiana) ile revizyon cerrahisi uygulanan üç olgu sunuldu. Tüm olgularda femur osteotomisi veya kortikal fenestrasyon olmaksızın, minimal invaziv endofemoral revizyon başarıyla yapıldı. Distal kırık femur başı, skopi altında delikli trepan tekniği ile temizlendi. Femur komponentinin revizyon artroplastisinde daha büyük Solution ${ }^{\mathrm{TM}}$ başlar kullanıldı. Endofemoral yaklaşım ameliyat süresini ve kan ve kemik kaybı miktarını azaltır. Kırık ve çimentosuz femur başlarında minimal invaziv teknik önerilmektedir.

Anahtar sözcükler: Femur başı; kırık; delikli trepan; poroz kaplamalı; revizyon.

diaphyseal fixation. A very stable secondary bone ingrowth occurs along the whole length of the coating. Good distal fixation actually leads to the fracture in the metaphyseo-diaphyseal junction of femoral component, particularly in the presence of proximal femoral bone loss. ${ }^{[4-7]}$ Fracture of a revised stem is a result of material fatigue, ${ }^{[4,8]}$ after a course without any complaints. Distal bone ingrowth of the prosthesis and present inadequate bone support ${ }^{[9]}$ in the metaphyseal region leads to increased stress of the revision femoral stem. The clinical signs of a stem fracture in intact

- Received: December 12, 2013 Accepted: March 14, 2014

- Correspondence: Libor Necas, M.D. Department of Orthopedics and Traumatology, University Hospital Martin, 03659 Martin, Slovakia Tel: +421434203355 Fax: +421434203355 e-mail: drnecas@hotmail.com 
femur are very subtle. Thigh pain or groin pain are usually present. There is neither dramatic leg length shortening nor severe gait instability. Plain X-ray is sufficient for diagnosis, however, the prosthetic fracture line may be overlooked. Good ingrowth of the distal part of femoral component is always present.

A fractured uncemented and extensively porouscoated stem often results in a revision procedure. Extended trochanteric osteotomy (ETO) for prosthesis retrieval is one option. ${ }^{[7,8]}$ It on the other hand is a relatively radical procedure. Cortical windows to the well-fixed distal part of the femoral prosthesis do not allow for an adequate access to remove broken components.

In addition, a less invasive procedure for removal of the well-fixed distal part of the stem has been proposed: hollow trephines (De Puy Moreland Cementless Extraction System, Leeds UK) which allow to overream the cylindrical distal part of the osteointegrated distal part of the prosthesis. ${ }^{[4,7,9,10]}$ It is possible to perform this procedure using an endomedular approach without femoral osteotomy. Subsequent bone loss is minimized in this procedure (Figure 1). If the prosthetic fracture line lies more proximal or the prosthesis has a higher diameter, reaming or cortex perforation may possibly occur.

From the view of technical aspect, it is demanding to explant the distal well-fixed component. Recent publications have shown different options for the

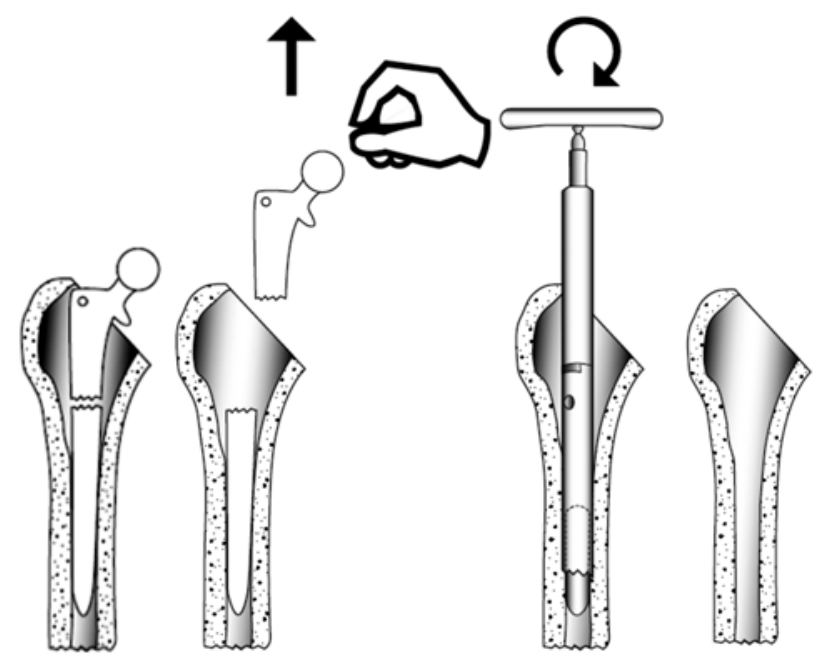

Figure 1. Line drawing of a broken revision fully porous-coated stem. Fracture of the stem appears in the matephyseo-diaphyseal junction. Loose proximal part is manually extracted. Firmly ingrown distal part is extracted with a hollow trephine. Free femoral canal is prepared for a longer and thicker femoral revision stem. solution of the underlying condition of the subsequent revision surgery. ${ }^{[10-12]}$ In addition, the use of hollow trephine reamers as a new strategy for removal of broken femoral mega-prostheses in modular total knee implants has been currently published..$^{[13]}$

In this article, we present three cases operated on by the same technique of explantation of the broken distal part of the component and for re-implantationoverreaming of femoral canal and bridging of the weakend part with a longer 10-inch femoral component. Herein, we can achieve long and strong press fit. The technique which is performed under fluoroscopy enables endofemoral approach without any cortical windows or osteotomies. We believe that this will be less invasive and safe and means that second revision would not create any new stress risers for the future.

To the best of our knowledge, this is the first report in European literature.

\section{CASE REPORT}

Case 1- A 51-year-old woman [156 cm, $65 \mathrm{~kg}$, body mass index (BMI) $\left.27 \mathrm{~kg} / \mathrm{m}^{2}\right]$ with developmental hip dysplasia in whom a Duraloc cup (De Puy Moreland Cementless Extraction System, Leeds UK) and Solution ${ }^{\mathrm{TM}}$ (DePuy, Warsaw, Indiana) (length 8", diameter $10.5 \mathrm{~mm}$ ) revision femoral component was implanted at the age of 47 presented with sudden pain in her thigh after previous revision THR. A cortical window was opened for cement removal from the tip of the stem.

She had two previous procedures in childhood and a cemented THR for secondary dysplastic osteoarthritis (OA) was implanted when she was 33-year-old.

Second revision surgery was performed 76 months after the first implantation of Solution ${ }^{\mathrm{TM}}$

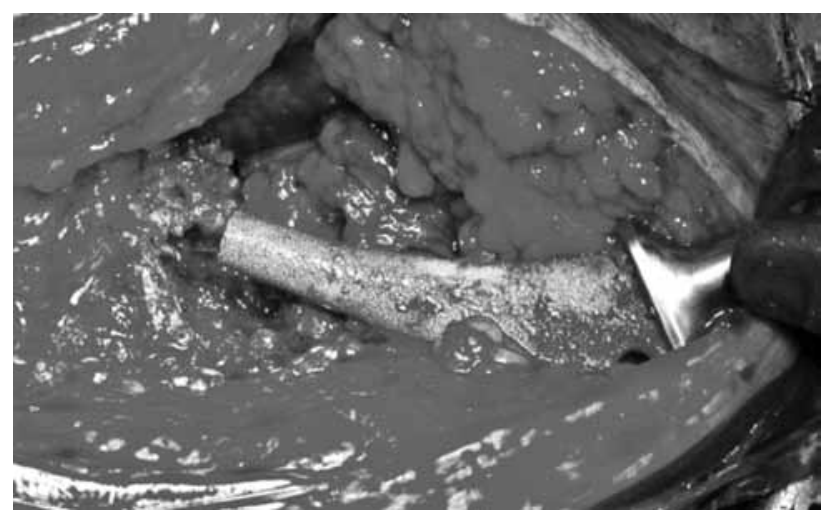

Figure 2. Manual extraction of a loose broken proximal part of fully porous-coated revision stem. 
stem. A minimally invasive revision of the femoral component was undertaken with manual extraction of the proximal part of the broken femoral Solution ${ }^{\mathrm{TM}}$ component (Figure 2). Distal fragment was removed by overreaming with a hollow trephine system under fluoroscopy (Figure 3). Gradually, the femoral canal was reamed to accommodate a $10^{\prime \prime} 15 \mathrm{~mm}^{\text {Solution }}{ }^{\mathrm{TM}}$ stem. The Duraloc shell was stable and a polyethylene liner was exchanged. In the last follow-up visit at 73 months, she had no clinical or radiological signs of THR insufficiency.

Case 2- A 55-year-old man $(165 \mathrm{~cm}, 93 \mathrm{~kg}$, BMI $34 \mathrm{~kg} / \mathrm{m}^{2}$ ) presented with a sudden-onset thigh pain. His previous operations included a THR with a hybrid system at the age of 50 and revision THR with Duraloc and an 8" Solution ${ }^{\mathrm{TM}}$ femoral component $12 \mathrm{~mm}$ was implanted at the age of 52. Extended trochanteric osteotomy was performed to gain access to the bone cement.

Second revision surgery was undertaken 38 month after the initial procedure. A minimally invasive endofemoral approach for stem retrieval was performed. Despite the hollow trephine breakage (Figure 4) at the tip of the distal fragment, the removal was successful. The femoral canal was reamed for a $10^{\prime \prime} 16.5 \mathrm{~mm}$ Solution $^{\mathrm{TM}}$ femoral component. The acetabular component was stable and the cup liner was exchanged. At 34 months, the patient was pain free without any signs of component instability.

Case 3- A 61-year-old woman $(171 \mathrm{~cm}, 75 \mathrm{~kg}$, BMI $\left.25.65 \mathrm{~kg} / \mathrm{m}^{2}\right)$ underwent THR at the age of 52 with
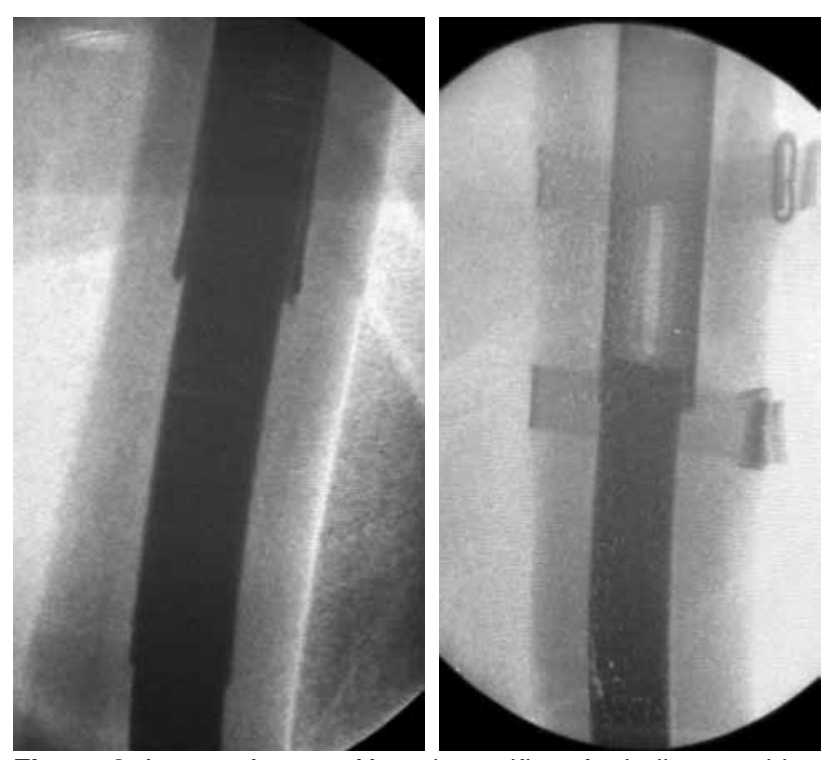

Figure 3. Images from an X-ray intensifier of a hollow trephine over a distal ingrown part of a broken femoral stem during revision surgery. a cemented THR. At the age of 58 a revision of both components with uncemented Duraloc acetabular component and 8 " Solution ${ }^{\mathrm{TM}}$ 10.5. Extended trochanteric osteotomy was performed during the initial revision to approach the cement in the femoral canal. She presented 32 months after the initial revision surgery with a sudden-onset thigh pain. Thirty-two months after the initial revision surgery, the patient underwent a second re-do.

The revision surgery was uneventful and the broken femoral component was removed. An uncomplicated manual extraction of proximal part of the component was performed and distal broken part of the stem was overreamed with the hollow trephine and extracted. After reaming of the femoral canal, a $10^{\prime \prime}$ Solution $^{\mathrm{TM}}$ component in $15.0 \mathrm{~mm}$ was implanted. The stable acetabular component was left in situ, a $28 \mathrm{~mm}$ polyethylene liner was changed. At 84 months after the last revision surgery, the patient was without complaints with stable components.

In our study, an anterolateral approach was used for the revision of fractured stem via the previous skin incision, slightly extended distally. Capsular tissue was removed and the hip dislocated. Gross instability of the proximal part of the stem was present. We took out the proximal femoral component portion without difficulty. Upon inspection, the findings were similar in all cases. In all patients, the acetabular component was well fixed. The polyethylene in the cup was exchanged during the second revision surgery. Macroscopically, there were no signs of toxic granuloma formation seen. The polyethylene cup liners have been intact, without gross delaminations. On visual inspection no infection signs have been noticed. Results of samples withdrawn for bacterial cultivation were negative. Small amount of metalosis and corrosion debris surrounding fracture level of the stem was found.

In each of the presented cases endofemoral revision of broken revision femoral component was successfully performed. In our cohort a shorter 6 " or 8 " version of revision stem was used in previous revision in all cases. All stems were in diameter under $13.5 \mathrm{~mm}$. Cemented stems were revised during first

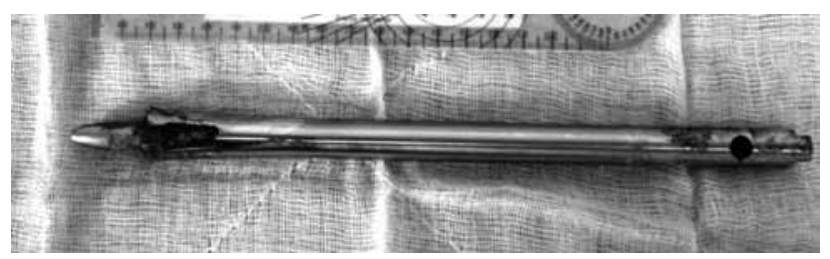

Figure 4. Broken hollow trephine after successful extraction of broken distal femoral revision stem. 
revision surgeries. The time to failure was 76,38 and 32 months respectively. The canal was then reamed and a new longer-10" version of fully porous coated femoral component was used. The diameter of the implanted revision femoral prosthesis increased by $4.5 \mathrm{~mm}$ in all cases, and three-size large prosthesis was used than the previous one (in component diameter).

One breakage of hollow trephine in time of endofemoral distal component retrieval was encountered. This did not change surgical approach and extraction of the distal part of prosthesis was successful. All three patients had an uneventful recovery without major complication in the postoperative period. Full weight bearing was allowed at 12 weeks postoperatively.

At the most recent follow-up (34, 73 and 84 months), all of the revised components had good function and patients were in good conditions without complaints. There was no septic complications in the follow-up period.

The procedure saves time needed for revision surgery. Blood loss using endofemoral approach is reduced. Full weight bearing at 12 weeks after revision and no complication in sense of trochanteric osteotomy non-union lead to superior functional outcome of endofemoral revision.

\section{DISCUSSION}

Fractures of ceramic head and ceramic insert have been reported. ${ }^{[14]}$ However fractures of femoral stem after primary THR are rarely seen. The fracture risk of both cemented and uncemented femoral stem is reported at approximately $0.27 \% .{ }^{[15]}$ Varus malposition of femoral stem, loosening of the stem, high physical activity and smaller diameter of the femoral stem are among the predisposing factors for femoral stem fracture after primary procedure. ${ }^{[15,16]}$ Inadequate osseous support in the proximal femur has been demonstrated to be a contributing risk factor to femoral stem fracture. ${ }^{[4]}$ In our series, one patient underwent ETO and one patient underwent a cortical window fenestration for cement removal during previous revision surgery.

Moreover, excessive body weight has been shown as a risk factor in several studies reporting fractured femoral stems. ${ }^{[4,16]}$ Our patients were also overweight with a BMI of $>25$ or obese with a BMI of $>30$.

Reported occurrence of fractures of the revision cementless cylindrical porous coated distally-fixed stems varies from $0.33 \%{ }^{[17]}$ to $2.3 \% .^{[4]}$ Higher body mass index $>30$, poor proximal femoral bone support and diameter of femoral component $<13.5 \mathrm{~mm}$ are factors associated with this complication. Modular revision hip systems show a comparable or even higher risk of prosthetic fracture at the mid stem junction, ${ }^{[18]}$ compared to cementless revision monolithic cylindrical stems.

Two previous reports describe a femoral revision prosthesis fracture in patients who underwent revision surgery prior to stem fracture using uncemented cobalt-chrome cylindrical distally fixed femoral prosthesis. ${ }^{[4,19]}$ As a part of previous revision procedure, ETO was found to be a risk factor for stem fracture. Four out of five patients with stem breakage underwent an ETO during prior revision surgery. ${ }^{[4]}$

Removal of a well-fixed distal anchoring part of an uncemented revision stem is challenging. Cylindrical stem enables the use of hollow trephines for component retrieval. Leaving the distal broken part of the stem in situ and using a custom-made rescue sleeve onto the existing stem is another option to solve a problem of prosthetic femoral component fracture. ${ }^{[10]}$ Retrograde approach to broken or loose femoral stem removal was currently advocated, using a retrograde femoral nail to tap out the femoral component from the femoral canal. ${ }^{[1]}$ Revision arthroplasty with a short femoral component in a fractured hydroxyapatite fully coated stem, leaving ingrown distal part in femoral canal, because of possible complication with component retrieval was also reported. ${ }^{[12]}$

To reduce the fracture risk of revision femoral uncemented extensively porous coated stem a diameter of prosthesis of over $13.5 \mathrm{~mm}$ is usually recommended. ${ }^{[9]}$ Bone grafting in the proximal part of femur during initial revision surgery may be also a preventive measure.

In cases of revision for a broken uncemented extensively porous coated distally fixed stem a minimally invasive technique using a hollow trephine technique is recommended. Endofemoral approach reduces the procedure time. The price for the trephine is less than for cables used to stabilise trochanteric osteotomy using transfemoral approach.

Subsequent bone loss by this procedure is minimized. If the prosthetic fracture line lies more proximal, or the prosthesis has higher diameter possible eccentric reaming to cortical bone or trephine disruption may occur. Trephine breakage was a complication during the revision surgery in one of the presented cases. Despite this complication extraction of the prosthesis was successful. 
Hollow trephines can also be used in selected cases for revision of broken femoral cemented stem, facilitating the extraction technique for this complication by far. Some of the so-called modern modular revision stems are also endangered by stem breakage. Endofemoral approach for re-revisions of total hip prosthesis is favored to more radical surgical approaches. Therefore, we anticipate that our contribution to this specific problem may facilitate endomedullar revision in this particular complication.

\section{Declaration of conflicting interests}

The authors declared no conflicts of interest with respect to the authorship and/or publication of this article.

\section{Funding}

The authors received no financial support for the research and/or authorship of this article.

\section{REFERENCES}

1. Mahomed NN, Barrett JA, Katz JN, Phillips CB, Losina E, Lew RA, et al. Rates and outcomes of primary and revision total hip replacement in the United States medicare population. J Bone Joint Surg [Am] 2003;85:27-32.

2. Berry DJ, Harmsen WS, Ilstrup D, Lewallen DG, Cabanela ME. Survivorship of uncemented proximally porous-coated femoral components. Clin Orthop Relat Res 1995;319:168-77.

3. Weeden SH, Paprosky WG. Minimal 11-year follow-up of extensively porous-coated stems in femoral revision total hip arthroplasty. J Arthroplasty 2002;17(4 Suppl 1):134-7.

4. Bush CA, Charles MN, Haydon CM, Bourne RB, Rorabeck $\mathrm{CH}$, MacDonald SJ, McCalden RW. Fractures of distallyfixed femoral stems after revision arthroplasty. J Bone Joint Surg [Br] 2005; 87:1333-6.

5. Paprosky WG, Weeden SH, Bowling JW. Component removal in revision total hip arthroplasty. Clin Orthop Rel Res 2001;393:181-93.

6. Meek RMD, Greidans NV, Garbus DS, Masri BA, Duncan CP. Extended trochanteric osteotomy: planing, surgical technique, and pitfalls. In: Helfet DL, editor. Instr Course Lect. Vol 53. Rosemont, IL: American Academy of
Orthopaedic Surgeons; 2004. p. 119-30.

7. Hozack WJ, Wade FA. Removal of components and cement. In: Callaghan JJ, Rosenberg AG, Rubash HE, editors. The adult hip. 2nd ed. Philadelphia: Lippincott Williams and Wilkins; 2007. p. 1352-70.

8. Teoh SH. Fatigue of biomaterials: a review. Int J Fatigue 2000;22:825-37.

9. Lu HC, Lin CL, Chang CW, Lai KA. Fracture of VerSys fully bead-coated long femoral stems: report on four fractures in 41 hips. Kaohsiung J Med Sci 2012;28:345-9.

10. Beal MD, Marchie A, Black E, Malchau H, Burke D. Treatment of a well-fixed modular fully porous coated stem after fracture using a custom rescue sleeve. J Arthroplasty 2010;25:1301-3.

11. Tóth K, Sisák K, Nagy J, Manó S, Csernátony Z. Retrograde stem removal in revision hip surgery: removing a loose or broken femoral component with a retrograde nail. Arch Orthop Trauma Surg 2010;130:813-8.

12. Sangüesa-Nebot MJ, Soriano FC, Gabarda RF, Mordt CV. Revision hip arthroplasty with a short femoral component in fractured hydroxyapatite fully coated femoral stem. J Arthroplasty 2010;25:1168.e13-6.

13. Tanaka T, Hamada K, Oshima K, Joyama S, Naka N, Araki N. A new strategy to remove broken femoral megaprostheses with hollow trephine reamers. Eur J Orthop Surg Traumatol 2013;23:357-60.

14. Bekler HI, Erdağ Y, Ozşahin M. Intrapelvic protrusion of the ceramic head resulting from forte ceramic liner fracture without a significant trauma: a case report. Eklem Hastalik Cerrahisi 2013;24:173-7.

15. Heck DA, Partridge CM, Reuben JD, Lanzer WL, Lewis CG, Keating EM. Prosthetic component failures in hip arthroplasty surgery. J Arthroplasty 1995;10:575-80.

16. Andriacchi TP, Galante JO, Belytschko TB, Hampton S. A stress analysis of the femoral stem in total hip prostheses. J Bone Joint Surg [Am] 1976;58:618-24.

17. Hamilton WG, Cashen DV, Ho H, Hopper RH Jr, Engh CA. Extensively porous-coated stems for femoral revision: a choice for all seasons. J Arthroplasty 2007;22:106-10.

18. Lakstein D, Eliaz N, Levi O, Backstein D, Kosashvili Y, Safir O, et al. Fracture of cementless femoral stems at the mid-stem junction in modular revision hip arthroplasty systems. J Bone Joint Surg [Am] 2011;93:57-65.

19. Sotereanos NG, Engh CA, Glassman AH, Macalino GE, Engh CA Jr. Cementless femoral components should be made from cobalt chrome. Clin Orthop Relat Res 1995;146-53. 